\title{
Mission in Suffering Context
}

\author{
Harianto GP \\ Ketua Sekolah Tinggi Teologi Excelsius
}

\begin{abstract}
This study aims to examine the mission in the context of suffering related to about theology of suffering, its context in Indonesia and its implications for mission in Indonesia. In connection with the goal, the results of the study show that suffering is the pressure faced by someone who comes from outside himself to exert a good influence on that person. The suffering of non-believers is different. If non-believers are suffering because of the world, but if believers suffer because of Christ. The suffering experienced by believers in Indonesia is indeed the Great Commission of Christ. Believers and the church are obliged to do God's mission is to win souls who are lost in their suffering by being a witness of God and dialogue to preach the gospel.
\end{abstract}

Keywords: Mission; Suffer; Church; Believers

\begin{abstract}
Abstrak
Penelitian ini bertujuan mengkaji mengenai misi dalam konteks penderitaan berkaitan dengan seputar teologi penderitaan, konteksnya di Indonesia dan implikasinya terhadap misi di Indonesia. Berkaitan dengan tujuan, hasil penelitian menunjukkan bahwa penderitaan ialah tekanan yang dihadapi seseorang yang datang dari luar dirinya untuk memberikan pengaruh yang baik kepada orang tersebut. Penderitaan orang yang bukan percaya dengan orang percaya berbeda. Kalau orang yang bukan percaya adalah penderitaan karena dunia tetapi kalau orang percaya menderita karena Kristus. Penderitaan yang dialami orang-orang percaya di Indonesia adalah memang amanat Agung Kristus. Orang percaya maupun gereja wajib melakukan misi Allah adalah memenangkan jiwa-jiwa yang tersesat dalam penderitaannya dengan cara adalah menjadi saksi Allah dan dialog untuk memberitakan Injil.
\end{abstract}

Kata Kunci: Misi; Penderitaan; Gereja; Orang Percaya 


\section{PENDAHULUAN}

"Agama" menjadi catatan pelanggaran HAM di Indonesia yang ditemukan sebagai berikut:

\section{Pertama, kasus Pelanggran HAM} yang terjadi di Maluku. Konflik dan kekerasan yang terjadi di Kepulauan Maluku sekarang telah berusia 2 tahun 5 bulan; untuk Maluku Utara $80 \%$ relatif aman, Maluku Tenggara $100 \%$ aman dan relatif stabil, sementara di kawasan Maluku Tengah (Pulau Ambon, Saparua, Haruku, Seram dan Buru) sampai saat ini masih belum aman dan khusus untuk Kota Ambon sangat sulit diprediksikan, beberapa waktu yang lalu sempat tenang tetapi sekitar 1 bulan yang lalu sampai sekarang telah terjadi aksi kekerasan lagi dengan modus yang baru ala ninja/penyusup yang melakukan operasinya di daerah - daerah perbatasan kawasan Islam dan Kristen (ada indikasi tentara dan masyarakat biasa). Akibat konflik/kekerasan ini tercatat 8000 orang tewas, sekitar 4000 orang luka - luka, ribuan rumah, perkantoran dan pasar dibakar, ratusan sekolah hancur serta terdapat 692.000 jiwa sebagai korban konflik yang sekarang telah menjadi pengungsi di dalam/luar Maluku.

Kedua, pelanggaran HAM atas nama Agama. Kita memiliki banyak sejarah gelap agamawi, entah itu dari kalangan gereja Protestan maupun gereja Katolik, entah dari aliran lainnya. Bahwa kadang justru dengan simbol agamawi, kita melupakan kasih, yaitu kasih yang menjadi 'atribut' Tuhan kita Yesus Kristus. Hal-hal ini dicatat dalam buku sejarah dan beberapa kali kisah-kisah tentang kekejaman gereja difilmkan. Salah satu contohnya dalam film The Scarlet Letter, film tentang hyprocricy Gereja Potestan yang 'menghakimi' seorang pezinah dan kelompok-kelompok yang dianggap bidat, ada lagi filmThe Magdalene Sisters, juga film A Song for A Raggy Boy, The Headman, "The Name of the Rose" , dan masih banyak lainnya. Kini, telah hadir film yang lumayan baru, yang diproduksi oleh Saul Zaentz dan disutradarai oleh Milos Forman, dua nama ini cukup memberi jaminan bahwa film yang dibuat mereka selalu bagus yaitu film Goya's Gost. Mungkin saja film Goya's Gost ini akan membuat 'marah' sebagian kelompok, namun apa yang dikemukakan oleh Zaentz dan Forman, sebagaimana kekejaman "Inkuisisi" telah tercatat dalam sejarah hitam Gereja. Kisah-kisah kekejamannya juga terekam dalam lukisan-lukisan karya Seniman Spanyol Francisco Goya (17461828), yang menjadi tokoh sentral dari film Goya's Gost ini. Kita telah mengenal banyak sekelompok manusia dengan atribut agama, berlindung dalam lembaga agama, mereka justru melakukan kejahatan kemanusiaan (crimes against humanity) entah itu Kristen, Islam atau agama apapun. Atas nama 'agama 
yang suci' mereka melakukan 'pelecehan yang tidak suci' kepada sesamanya manusia. ${ }^{1}$

Artikel ini bertujuan untuk menjawab beberapa pertanyaan sebagai berikut: Apakah yang dimaksud dengan teologi suffering (penderitaan)? Bagaimanakah penderitaan dengan konteks misi di Indonesia? Bagaimanakah implikasi terhadap misi terhadap konteks di Indonesia?

\section{ANALISIS DAN PEMBAHASAN}

\section{Definisi "Suffering"}

Penderitaan dari kata dasar derita (pascho), yang di dalam PB dipakai sebanyak 42 kali. $^{2}$ Penderitaan ialah tekanan yang dihadapi seseorang yang datang dari luar dirinya untuk memberikan pengaruh yang baik kepada orang tersebut, tetapi penderitaan itu juga suatu usaha pengacaukan ke dalam ciptaan ini. ${ }^{3}$ Dalam hal ini, maka Markus 8:31; 9:31 dan 10:3334 merupakan petunjuk jelas bahwa memang

\footnotetext{
${ }^{1}$ http://intanshawolarea.wordpress.com/2013 /10/07/kasus-kasus-pelanggaran-ham-di-indonesia/ (Diakses 20 Maret 2014). Sebelumnya, ditengahtengah 'isu anti terorisme (Islam)', sutradara Inggris, Ridley Scott memproduksi film The Kingdom of Heaven, barangkali bisa juga digunakan untuk menyindir Presiden Bush yang sering menggunakan kata"crusades" dalam pidatonya. Film The Kingdom of Heaven adalah sebuah 'otokritik' bagi Kekristenan, dan sajian 'ironisme' dari ajaran Kristus yang penuh kasih. Bahwa perang Salib yang telah terjadi selama 4 abad itu bukanlah suatu kesaksian yang baik, tetapi lebih merupakan sejarah hitam. Dibawah ini review dari sebuah film, tentang kejahatan dibawah payung Agama, bukan berniat melecehkan suatu Agama/ Aliran tertentu, melainkan sebagai perenungan apakah perlakuan seseorang melawan/menindas orang lain yang tidak 'seagama' itu tujuannya membela Allah?
}

Yesus menerima dan melakukan pekerjaan seorang Mesianik. Dia menerima pekerjaan untuk menderita. Markus 8:31 berbunyi: "Kemudian mulailah Yesus mengajarkan kepada mereka, bahwa Anak Manusia harus

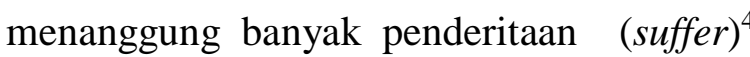
dan ditolak oleh tua-tua, imam-imam kepala dan ahli-ahli Taurat, lalu dibunuh dan bangkit sesudah tiga hari".

C.S. Lewis mengatakan bahwa penderitaan ${ }^{5}$ adalah warisan eksistensi dunia jiwa [manusia] hidup di bumi. Jiwa itu menjadi sakit mungkin dikarenakan luka dari orang lain. Di situ manusia menderita. Manusia, bukan Allah, yang membuat manusia itu menderita: racks, whips, prisons, slavery, guns, bayonets, dan bombs. ${ }^{6}$ Selanjutnya menurut Paul J. Lindell menbatakan bahwa penderitaan itu bukan imajinasi, bukan beberapa mimpi buruk, sebaliknya adalah nyata, aktual, tetapi bukan akademik. Penderitaan itu datang ketika

membela tradisi? membela doktrin, ataukah membela diri sendiri?

${ }^{2}$ Everret F. Harrison, Baker's Dictionary of Theology (Michigan: Baker Book House, 1988) 505.

${ }^{3}$ JD Douglas, New Bible Dictionary (England: Inter-Varsity Press, t.th.) 182.

${ }^{4}$ Patein; pres., infinitif, dari akar kata pateo, artinya "suffer".

5"Suffering" sinonim dengan "pain", "anguish", "tribulation", dan "adversity".

${ }^{6}$ C.S. Lewis, The Problem of Pain (New York: The Macmillan Co., 1994) 89. Bandingkan dengan Ralph W. Sockman, Makna Penderitaan (Malang: Gandum Mas, tp. th.) 23 mengatakan bahwa Penderitaan adalah suatu kesakitan sebagai nada perasaan yang berlawanan dengan kesenangan. Keadaan yang tidak menyenangkan dalam semua bentuk dan tingkatannya. 
manusia itu lahir. Manusia tidak dapat meloloskan diri dari penderitaan. Penderitaan itu datang dari berbagai sudut kehidupan. ${ }^{7}$ Penderitaan itu datang dari hubungan yang terputus dengan Allah. Dimulai dari kegagalan hubungan Adam dan Hawa dengan Allah, maka manusia mulai merasakan penderitaan.

Berkaitan hal tersebut, maka Thomas tidak melihat penderitaan secara metafisik. Sebaliknya, ia memahaminya sebagai sesuatu yang ada di antara masyarakat dalam bentuk kemiskinan, sebagai dari struktur masyarakat yang tidak adil, yang menimbulkan situasi kaum tertindaspenindas. Penderitaan ini semakin parah, karena rakyat sendiri -- contohnya di India menerima posisi tertindas mereka secara fatalistis. Ini terbukti pada masa dominasi Barat ketika rakyat percaya bahwa dominasi oleh kekuasaan imperialistis Barat tergolong pada Providentia Dei. ${ }^{8}$

Thomas memberi kasus penderitaan India masih berada dalam situasi penderitaan, dalam pola-pola masyarakat tradisional maupun dalam masyarakat modern. Dalam masyarakat tradisional, mereka tunduk pada kebiasaan dan adat tradisional, di mana hakhak individu seringkali tidak dianggap, sementara dalam masyarakat modern, di

${ }^{7}$ Paul J. Lindell, The Mystery of Pain (Jerman: Editions Trobisch, 1982) 11-12.

${ }^{8}$ M.M. Thomas, The Christian Rerponse in the Asian Revolution (London: 1966) 12. mana ideologi-ideologi memainkan peranan penting, rakyat menjadi korban dari konflik ideologi.

\section{Mesias sebagai Hamba yang Menderita}

Satu-satunya pilihan yang dapat dilakukan manusia untuk menghindari alternatif kehancuran diri dalam kemerdekaan (mesianisme yang menaklukkan) dan bertahan melalui pengunduran diri pada istirahat "rohani" yang tidak bebas. Berkaitan hal tersebut, maka Thomas mengatakan bahwa menerima mesianisme hamba yang menderita. Karena itu, kita perlu mengakui Kristus yang tersalib sebagai satu-satunya Tuhan kehidupan "Situasi kekafiran baru" dalam dunia masa kini, tetapi orang-orang Kristen terpanggil untuk memperlihatkan pertolongan pertobatan mereka secara terbuka, sehingga dapat menjadi suatu komunitas saksi yang meladani pola kehidupan hamba yang menderita ini. ${ }^{9}$ Bagi Thomas, Kristus yang menderita ini tidak lain daripada Allah sendiri. Allah ini (melalui Kristus yang menderita) bukanlah Allah yang tidak perduli. Allah sendiri hadir di tengah-tengah penderitaan dan kesengsaraan. Allah ada di tengah kelaparan itu. Allah bahkan mati bersama mereka yang mati. ${ }^{10}$

${ }^{9}$ M.M. Thomas, Man and the Universe 95.

${ }^{10}$ A.A. Yewangoe, Theologia Crucis di Asia (Jakarta: Gunung Mulia, 1989) 105. 
Choan Seng Song melihat berbeda terhadap yang yang diutarakan oleh Thomas. Dasar biblika penderitaan bagi Choan Seng Song, adalah pengalaman Paskah ${ }^{11}$ terjadi dalam Alkitab yang telah menghasilkan suatu perubahan dasariah. Jeremias mengutip analisis Song mengatakan bahwa ada tiga ramalan penderitaan dalam Markus 8:31 (Mat 16:21; Luk 9:22); 9:31 (Mat 17:21; Luk 17:21; Luk 9:44) dan 10: 33-34 (Mat 20:1819; Luk 18: 32-3) sebagai kisah yang disusun ex eventu. ${ }^{12}$ Urut-urutan peristiwa yang berkaitan dengan penderitaan Yesus -[sebagai manusia yang hidupnya dihina, dicaci-maki, dicambuk, disiksa, bahkan disalibkan. Penderitaan ini rasa sakit secara fisik -- dalam nas-nas di atas, khususnya dalam bentuk yang paling terinci dalam Markus 1:33-34. Jeremias berkata:

Berhubungan dengan begitu tepat dengan jalannya kisah penderitaan dan kisah Paskah, bahkan sampai rinciannya, hingga tak pelak lagi bahwa ramalan penderitaan ini adalah ringkasan dari penderitaan yang dirumuskan setelah kejadiannya. ${ }^{13}$

Penderitaan jabatan Mesianis Yesus terkait dengan "Nyanyian-nyanyian TUHAN" dalam Yesaya 53. Dalam khotbah

\footnotetext{
${ }^{11}$ Pengalaman perayaan pembebasan bangsa Israel dari Mesir. Anak-anak sulung orang Mesir dibunuh, tetapi pintu-pintu rumah orang Ibrani "dilewati” (Ibrani Pesah berarti melewati). Peristiwa itu diperingati dengan mengadakan perjamuan Paskah di mana para perseta "makan paskah" yaitu makan "korban Paskah" atau anak domba Paskah itu (Kel 12: 23-28, 43-51). Dalam Perjanjian Baru Yesus Kristus disebut "anak domba paskah" (1Kor 5:7) atau "Anak Domba yang disembelih" (Why 5:6). Untuk jemaat
}

Pentakosta Petrus, Kristus yang disalibkan dan bangkit itu menjadi tema utama; kepadaNyalah seluruh perjalanan Israel yang dikisahkannya berlangsung (Kis. 2: 14-36). Kembali dalam percakapannya di serambi Salomo di kemudian hari, Petrus berkisah tentang "Allah Abraham, Ishak dan Yakub, Allah nenek moyang kita sampai Mesianis yang diutus-Nya harus menderita" (Kis. 3: 13-26).

Bagi Song, dalam Markus 10:45 kita mendapatkan teologi paling ringkas dari jabatan mesias yang menderita, “Anak Manusia datang untuk melayani dan untuk memberikan nyawa-Nya menjadi tebusan bagi banyak orang. Penderitaan yang dialami mesias bukan demi diri-Nya sendiri, melainkan demi “orang banyak", yaitu demi mereka yang tidak terhitung banyaknya.

Penderitaan Yesus, Sang Mesias telah menyingkirkan segala halangan manusia. Penderitaan ini membuat Allah tersedia bagi umat manusia dan memampukan mereka menjadi bagian dari misteri keselamatan ilahi. Kedalaman penderitaan Allah haruslah menjadi tempat di mana orang-orang, kendati latar belakang dan tradisinya berbeda-beda, dapat saling mengakui yang lain sebagai sesama peziarah yang membutuhkan kuasa penyelamatan Allah. ${ }^{14}$

Purba hari Paskah mendapat isi baru, yaitu peryaaan kebangkitan Tuhan.

${ }^{12}$ Ex eventu adalah sesuatu yang disimpulkan dari suatu peristiwa.

${ }^{13}$ Lih. Joachim Jeremias, New Testament

Theology I: Proclamation of Jesus (London: SCM Press, 1971) 276, 277-299.

${ }^{14}$ Choan-Seng Song, Allah yang Turut Menderita (Jakarta: Gunung Mulia, 1993) 164; juga 
Salib Puncak Yesus "Suffering"

$$
\text { Kata "suffer" sebagai penderitaan }
$$
Kristus $^{15}$ menunjuk pada kehidupan pelayanan Yesus. Ini cukup eksklusif pada kematian-Nya. Juga menunjuk kepada penderitaan sebagai manusia saat Ia dicobai. Penderitaan-Nya ini bukan sebuah peristiwa saja, tetapi keilahian-Nya (kebutuhan keillahian-Nya) berperan untuk menujuk keselamatan manusia. $^{16}$ R. Alan Cole menyebut "a thelogical shorthand" (steno) untuk kematian-Nya hingga di kayu salib (Kis. $\quad 3: 18) .{ }^{17}$ Ibrani 5:8 menunjukan semakin jelas bahwa salib itu puncak dan mempunyai nilai Yang Maha Tinggi dari kehidupan penderitaan Yesus. Hal ini bisa kita pahami bila kita sudah mengenal pribadi Kristus sehingga kita bisa menghargai pekerjaan-Nya.

Dengan demikian bahwa Markus 8:31 merupakan pemberitahuan penderitaan pertama (pararel dengan Mat 16:21 Ia harus pergi menanggung banyak penderitaan; juga Luk. 9:22), yang kemudian dilanjutkan dengan Markus 9:31 sebagai pemberitahuan penderitaan kedua (pararel dengan Mat.

baca C.S. Song, Jesus and the Reign of God (Minneapolis: Augsburg Fortress, 1993) 161-167.

${ }^{15}$ TDNT, 912-913.

${ }^{16}$ NIDNTT,721; dalam PB menujuk pada penderitaan Kristus sendiri dan penderitaan orangorang Kristen demi Kristus. Dalam Ibrani dan 1 Petrus, pasko digunakan dalam hubungan kesengsaraan Kristus, diikuti dari konsep Lukas dan Kisah Para Rasul, di mana artinya: "to die". Aplikasi ini hanya terjadi dalam Ibrani dan 1 Petrus di dalam
17:21; Luk. 17:21; dan Luk. 9:44) sebagai berikut: "Sebab ia sedang mengajar muridmurid-Nya. Ia berkata kepada mereka: “Anak Manusia akan diserahkan ke dalam tangan manusia, dan mereka akan membunuh Dia, dan tiga hari sesudah Ia dibunuh Ia akan bangkit” (Mrk. 9:31). Di sini bahwa Markus 9: 31 memang tidak memunculkan kata "suffer" tetapi keseluruhan ayat tersebut menunjukkan kelengkapan penderitaan yang Yesus alami. R. Alan Cole melihat Allah yang hadir dalam diri Yesus melakukan aktifitas-Nya dalam peristiwa tersebut. ${ }^{18}$ Ini merupakan suatu pukulan bagi Mesias yang ditolak oleh bangsa Israel sebagai Mesiasnya, sehingga terjadi pergeseran bahwa Mesias diterima oleh bangsa di luar Israel. Ini adalah jalan salib (Kis. 2:23). Kondisi ini dipertegas lagi dalam Markus 10: 33-34 pemberitahuan penderitaan ketiga (pararel dengan Mat. 20:18-19; Luk. 18: 32-3) sebagai rangkaian penderitaan Yesus, yaitu:

Kata-Nya: "Sekarang kita pergi ke
Yerusalem dan Anak Manusia akan
diserahkan kepada imam-imam kepala dan
ahli-ahli Taurat, dan mereka akan menjatuhi
Dia hukuman mati. Dan mereka akan
menyerahkan Dia kepada bangsa-bangsa
yang tidak mengenal Allah, dan Ia akan
diolok-olokkan, diludahi, disesah dan

PB. Di mana penderitaan orang Kristen mengarah pada: (1) menderita karena persekutuan dengan Kristus. Ini merupakan konsep dari koinonia (persekutuan), (2) mengarah pada eskatalogi. Penderitaan orang Kristen akan diakhiri dengan kedatangan Kerajaan Allah.

${ }^{17} \mathrm{R}$. Alan Cole, Mark, TNTC (Grand Rapids: Eerdmans, 1989) 205.

${ }^{18}$ R. Alan Cole, Mark 219. 
dibunuh, dan sesudah tiga hari Ia akan bangkit.

Disalibkan berarti Yesus tidak saja menderita tetapi manusia yang lain (orang percaya) juga menderita dalam nama-Nya. Song melanjutkan: "By people I mean those men, women, and children, in Jesus' day, today, and in the days to come, economically exploited, polotically oppressed, culturally and religiously alienated, sexually, racially, or class-wise discriminated against."19

Sebenarnya penderita yang dialami oleh Yesus sudah merupakan rancangan Allah jauh ke belakang. Yesaya 53: 2-3 sudah mengatakan bahwa Yesus sebagai tunas dari tanah kering (ay. 2). Lalu, Yesus dihina dan dihindari orang, seorang yang penuh kesengsaraan dan yang biasa menderita kesakitan; ia sangat dihina, sehingga orang menutup mukanya terhadap dia dan bagi kita pun dia tidak masuk hitungan (ay. 3). ${ }^{20}$ Berkaitan hal di atas, maka Song menulis:

\footnotetext{
${ }^{19}$ Ibid., 216.

${ }^{20}$ Bahkan ada beberapa catatan yang mendukung dengan kuat penderitaan yang dialami Yesus seperti dalam Mat 24:8; Mrk 13:8: "Ia penderitaan menjelang zaman baru"; Mat 17:12: "Anak manusia akan menderita"; Mrk 8:31; Luk 9:22; 17:25: "Anak manusia harus menanggung banyak penderitaan"; Mrk 9:12: "ada tertulis anak manusia akan menderita dan akan dihina ..."; Luk 24:26, Kis 3:18; 26:23: "Mesias (yang diutus) harus menderita semuanya itu, sengsara"; Luk 24: 46; Kis 17:3: "Mesias harus menderita dan bangkit".
}

Sebagai orang Kristen, kita harus kembali pada Yesus seperti yang disaksikan oleh Alkitab. Semakin banyak saya renungkan, semakin dalam saya merasa kagum oleh tokoh Yesus itu. Di sini kita tak perlu persoalkan apakah Yesus itu Anak Allah, atau Anak Maria. Namun kita menjadi begitu terpesona, menjadi kagum oleh sosok yang bernama Yesus itu. Bagaimana Ia memberi kuasa-Nya, sehingga kita memiliki "insight", imajinasi untuk menantang dan mematahkan norma-norma tradisional, walaupun pada akhirnya Ia harus mati. Ya, sebab tubuh-Nya telah terpecah, maka kita dimampukan untuk menimbang ulang sikap-sikap kita terhadap budaya kita sendiri. $^{21}$

\section{Proses Penderitaan}

Penderitaan adalah proses. Ketika penderitaan itu datang kepada kita, maka kita bertanggung jawab kepada penderitaan itu. Di sini penderitaan orang percaya [new creation] berbeda dengan penderitaan sebelum percaya (old creation). Sebelum percaya, ia menderita sebagai orang belum percaya dan ia percaya, ia menderita sebagai orang percaya. Berkaitan hal ini, Lewis mengatakan bahwa rasa sakit jasmaniah sama sekali bukan merupakan tetesan yang terpahit dalam cawan penderitaan. Beberapa bentuk rasa sakit jasmaniah bisa menyenangkan juga. Buktinya, tak seorang

${ }^{21}$ Ibid., 41; baca juga C. S. Song, "Dunia Citra-citra dan Lambang-lambang", Persetia of Theological Education Series, 1992, 3 dikatakan bahwa imajinasi adalah tenaga kehidupan manusia. Tanpa imajinasi, kehidupan manusia akan terutama dikendalikan oleh naluri-naluri hewani untuk mempertahankan hidup dan oleh kesibukan memenuhi kebutuhan-kebutuhan biologis. Imajinasi adalah kekuatan transendensi-diri manusia. Ia memberi kita kemerdekaan dari batasan waktu dan ruang. Kita hidup di dalam waktu kini, tetapi kita bukanlah untuk memindahkan diri kita sendiri dari masa kini ke masa lampau dan ke masa depan. 
pun yang merisaukan proses "hangat - enak hangatnya - terlalu panas - menyengat", yang mengingatkan dia [orang itu] agar menarik tangannya dari panas api. "Kalau saya boleh mempercayai perasaan saya sendiri bahwa rasa sakit sedikit di kaki-kaki saya sering terjadi bila hendak naik tempat tidur karena saya baru saja menempuh perjalanan yang jauh. Memang saya merasakan sakit, tetapi tidak membuat saya menderita, melainkan sangat menyenangkan."22

Rasa sakit tidak meninggalkan kuman yang beracun atau yang hidup terusmenerus. Apabila sudah berakhir, ya berakhir saja, dan akibatnya yang wajar ialah rasa sukacita. Setelah berbuat kesalahan, seseorang bukan saja harus meniadakan kesalahan itu. Setelah berbuat dosa, maka seseorang tidak hanya menghilangkan godaannya, tetapi harus kembali dan bertobat dari dosa itu sendiri. Dalam setiap kasus diminta tindakan "penghapusan”. Rasa sakit menghendaki "penghapusan" seperti itu. Mungkin, seseorang harus menyembuhkan penyakit yang menyebabkannya, apabila sudah berakhir, maka rasa sakit itu mrenjadi steril. $^{23}$

Lewis menyarankan bahwa penderitaan itu bisa dipecahkan jika kita

${ }^{22}$ Ibid., 20.

${ }^{23}$ Ibid., 104.

${ }^{24}$ C.S. Lewis, The Problem of Pain (New York: The Macmillan Co., 1994) 36. Pemikiran C.S. mempunyai pengertian yang cukup tinggi tentang Allah dan tentang kasih. Kita perlu berpikir bahwa Allah ada untuk melayani kita. Bukan itu peranan-Nya. Kita berada di sini untuk melayani Dia. Dialah pihak pertama sedangkan kita adalah pihak kedua. Karena itu, jangan kita mengukur keadilanNya menurut cara Ia memperlakukan kita. Skala itu terlampau kecil. Lagi pula, jangan kita mengukur kasih-Nya menurut kebahagiaan yang kita rasakan. Bagaimana perasaan saudara mengenai kasih seseorang teman, jika ia berusaha membahagiakan saudara meskipun saudara tidak jujur dan tidak hidup suci? Kasihnya begitu berati bukan? ${ }^{24}$

Penderitaan itu tidak baik bagi diri seseorang tetapi bila penderitaan itu terjadi bagi seseorang ia taat hidup dalam kehendak Allah maka orang itu hidup dalam arah yang tepat dan bertindak dalam mercy. Orang itu bukan mengalami hidup yang gagal tetapi ia: pertama, hidup dalam kebaikan Allah. Kedua, hidup dalam kejahatan yang dikarenakan oleh keberdosaan manusia. Ketiga, karena tujuan penebusan Allah. Keempat, kebaikan yang komplek yang menerima penderitaan dan menolak kontribusi dosa. ${ }^{25}$ Bagi Lewis, memang penderitaan itu misteri, tetapi penderitaan itu

Lewis tersebut juga menjadi bagian dukungan Ralph W. Sockman, Makna Penderitaan (Malang: Gandum Mas, tp. th.) 22 .

${ }^{25}$ Ibid., 110. 
tidak membuat orang percaya bertambah jahat melainkan menghasilkan orang percaya yang bertambah baik dalam segala tindakannya - menjadi saleh. Tidak ada orang yang menderita dua kali lipat (melebihi kemampuannya): melebihi seluruh waktu, melebihi seluruh tempat dan ia tidak akan menemukan composite pain in anyone's consciousness. Karena semua penderitaan itu sifatnya universal dan semua orang pasti mengalaminya. Selama kita hidup di dunia, penderitaan itu hanya sterilised or disinfected evil. Setelah kita steril dari penderitaan sebelumnya, kemudian kita kembali menderita dikarenakan hal-hal yang lain (kehidupan berikutnya). ${ }^{26}$

\section{Faktor-faktor Penyebab Penderitaan}

Bagi Paul, penderitaan disebabkan empat hal sebagai berikut: karena penderitaan fisik, karena penderitaan teror perang, karena penderitaan bencana alam, dan karena kematian, kecelakaan atau problem yang datang dari orang lain. ${ }^{27}$ Sikap terhadap penderitaan adalah hidup dalam

\footnotetext{
${ }^{26}$ Ibid., 117.

${ }^{27}$ Ibid., 20-21. Bandingkan dengan Ralph W. Sochman, Makna Penderitaan (Malang: Gandum Mas, tp. th.) 1-19 mengatakan bahwa Penderitaan manusia dibagi menjadi dua, sebagai berikut: pertama, penderitaan yang bisa dipahami oleh manusia seperti: dosa, kesalahan perorangan, penderitaan bersama, disebabkan oleh musuh-musuh, Kedua, penderitaan yang tidak dapat kita pahamai seperti: nasib atau peruntungan (Pkh 9:11; Nasib (peruntungan) menyukai pikiran yang terlatih dan tidak menggandalkan iman. Misalnya dalam perjudian, maka penjudi biasanya menekankan
}

kebaikan karena sifat manusia adalah baik dan hidup dalam pengharapan kebangkitan manusia. $^{28}$

\section{Akibat dari Penderitaan}

Berkat dari penderitaan yang dialami oleh manusia sebagai berikut: hidupnya the way of cleansing, to illuminate our calling, a corrective for distorted vision, helps us think of others, affects worship, dan moves people to pray. ${ }^{29}$

\section{$\underline{\text { Yesus sebagai Pusat Misi Pembebasan }}$ Penderitaan di Dunia Menurut Song, Yesus adalah jawab} dari krisis kehidupan di dunia yang melanda segala aspek kehidupan termasuk perbedaan menyolok antara perbedaan si kaya dan si miskin. Bukan Yesus tetapi hidup di dunia ini banyak problem, dan Yesus membuat keberadaan manusia menjadi hidup. Maksudnya, kehidupan sebagai eksistensi fisik (bios) dan hidup sebagai spiritual (zoe) adalah merupakan satu kesatuan hidup (nephes).${ }^{30}$ Di sini, teologia dimulai dari hati

\footnotetext{
"nasib" untuk memang atau kalah.), kecelakaankecelakaan, dan takdir Allah (Suatu kejadian yang tak terelakkan yang terjadi karena kerjanya alam tanpa campur tangan manusia atau tanpa disebabkan kelalian manusia. Yang digolongkan takdir Allah kejadian-kejadian seperti: gempa bumi, halilintar, badai).

${ }^{28}$ Ibid., 30-34.

${ }^{29}$ Ibid., 41-48.

${ }^{30}$ C. S. Song, "Jesus Christ - The Life of the World - an Asian Meditation" East Asia Jurnal of Theology, Vol.1 No. 1 1983, 117.
} 
Allah yang disebabkan oleh penderitaan dan rasa sakit manusia. Penderitaan yang dialami manusia menyentuh hati Allah. Sehingga, untuk mengatasi penderitaan itu, Allah menawarkan Yesus Kristus menderita ${ }^{31}$ agar Yesus bisa meneladani eksistensi manusia untuk lepas dari krisis dunia. Di sini Yesus ditakdirkan untuk memikul dosa (eksistensi) manusia itu sehingga Yesus Kristus merubah dirinya menjadi manusia dan hidup dalam dunia. $^{32}$

Di sini Yesus sebagai pusat misi memberi pengalaman yang nyata bahwa Yesus adalah Gereja Tuhan. Gereja ini menjadi fenomena sosial dan Yesus itu pusat misi yang diberitakan dalam sejarah dunia. ${ }^{33}$ Lebih dalam Song mengatakan:

\begin{abstract}
Yang sangat penting bahwa manusia dapat ditangkap menjadi bebas dari penderitaan di dunia ini. Kenyataannya, manusia sangat stress dalam kehidupannya dibuat menjadi selamat. Untuk keselamatan ini, bagi orangorang Kristen dimengerti sebagai kesalahan dari sesuatu yang tidak ada. ${ }^{34}$
\end{abstract}

\section{Mengatasi Penderitaan}

Jelas penderitaan yang dialami oleh Yesus merupakan teladan hidup yang mesti dijadikan contoh oleh orang-orang Kristen dalam kehidupannya sehari-hari. Jadi, kalau Yesus hidup menderita maka orang Kristen pun hidup dalam penderitaan-Nya. Berkaitan

${ }^{31} \mathrm{C}$. S. Song, Third-Eye Theology (Maryknoll: Orbis Books, 1979) 119.

${ }^{32}$ Ibid., 118.

${ }^{33}$ Choan-Seng Song, Christian Mission in Reconstruction: An Asian Analysis (Maryknoll: Orbis Books, 1977) 66. hal tersebut, maka ada dua hal adalah: (1) Implikasi Perseverance of the Saints bagi penginjilan: ketahanan atau ketekunan merupakan suatu wujud ketaatan misionaris kepada panggilan Tuhan. (2) Pernyataan Reformed mengenai perseveranve of the Saints: Orang pilihan tidak hanya ditebus oleh Kristus dan dilahirbarukan oleh Roh Kudus, mereka juga dipelihara oleh iman dalam kekautan Allah (1Ptr. 1: 3-5), tidak ada yang dapat dipisahkan dari kasih Kristus yang kekal (Rm. 8: 34-39). (3) Dasar Alkitabiah mengenai perseverance of the saints: ketahanan orang-orang kudus (Perseverance of the Saints) bukan hanya pernyataan Reformed, melainkan juga ajaran Alkitab. Pengakuan Iman Westminster mengemukakan ajaran Alkitab. Pengakuan iman Wesminster mengemukakan ajaran Alkitab mengenai ketahanan orang-orang kudus, bahwa orang-orang pilihan pasti akan bertahan sampai akhirnya dan mengalamai keselamatan yang kekal (Flp.1:6; 2Ptr. 1:10; Yoh. 10: 28-29, dst.). Ketahanan orang-orang pilihan adalah berdasarkan pada keputusan pemilihan Allah yang kekal (2 Tim. 2: 18-19, Yer. 31:3). ${ }^{35}$

\footnotetext{
${ }^{34}$ Ibid., 69.
}

${ }^{35}$ Stevri I. Lumintang, Misiologia Kontemporer (Batu: Departemen Multi-Media YPPII: 200(9) 370. 


\section{Konteks Mission In Indonesia}

Sejarah kekristenan di Indonesia merupakan sejarah "penderitaan" yang panjang di mana terjadi adanya berbagai tekanan-tekanan dari orang di luar terhadap penelitian FKKS-FKKI mengatakan:

Dari tahun 1945 sampai tahun 1997 telah terjadi 385 gereja yang ditutup, dirusak atau dibakar di Indonesia, dan bila dirata-ratakan per tahun sekitar 44, 5\%. Distribusi kejadian perusakan gereja 18945-Mei 1997 sebagai berikut: Jatim 102 gereja, Jabar 72 gereja, Jateng 45 gereja, Sulsel 36 gereja, Kalimantan 30 gereja, DKI Jaya 21 gereja, Sumut dan Aceh 12 gereja, DI Yogyakarta 10 gereja, Sumsel dan Lampung 7 gereja, Bali 18 gereja, dan daerah lain 18 gereja. ${ }^{36}$

Hingga Agustus 2000 sedikitnya 758 gedung gereja yang ditutup, dirusak, dan atau dibakar - 144 gedung gereja dirusak dan atau dibakar selama pemerintahan KH. Abdurrahman Wahid. Di luar data tersebut pasti masih ada sekian banyak gedung gereja yang mengalami nasib yang sama. ${ }^{37}$

Dalam buku Batu-batu

Tersembunyi $^{38}$ dirincikan bahwa perusakan, penutupan, pembakaran gereja di Indonesia sebagai berikut: selama pemerintahan Presiden Pertama RI Soekarno, 17 Agustus 1945- 7 Maret 1967 terjadi dua gereja (ratarata per bulan 0,0008 gereja). Selama pemerintahan Presiden kedua RI Soeharto, 7 Maret 1967 -21 Mei 1988 terjadi 456 gereja (rata-rata per bulan 1,19 gereja). Selama pemerintahan Presiden ketiga RI Habibie, 21 Mei 1998 - 20 Oktober 1999, terdapat 156

${ }^{36}$ Paul Tahalele , dkk. (ed.), Beginikah Kristiani Surabaya, 1997) 39-45.

${ }^{37}$ Editorial Berita FKKI, Edisi 20, Agustus kehidupan kekristenan itu sendiri. Data Kemerdekaan Kita (Surabaya: Forum Komunikasi

gereja (rata-rata per bulan adalah 9,18 gereja). Selama pemerintahan Presiden keempat RI Abdurrahman Wahid, 20 Oktober 1999 - 23 Juli 2001 terdapat 232 gereja (rata-rata per bulan adalah 11,05 gereja). Selama pemerintahan Presiden kelima RI Megawati Soekarno Putri, 23 Juli 2001 sampai Nopember 2001 terdapat 12 gereja (rata-rata per bulan terdapat 3 gereja). Jadi, total sampai Nopember 2001 terdapat 858 gedung gereja di Indonesia ddirusak, ditutup, dibakar dan diteror.

Keadaan yang menekan orang-orang Percaya bukan terjadi di gereja-gereja saja tetapi juga di seminari-seminari, bahkan pribadi-pribadi orang Percaya -- yang banyak ditemukan teraniaya bahkan terbunuh dalam keadaan tubuhnya terpisah dengan kepalanya. Berkaitan hal ini, maka mantan panglima Kodam Siliwangi Mayjen Tayo Tarmadi $^{39}$ mengatakan:

Peristiwa kerusuhan yang terjadi dimungkinkan direkayasa sedemikian rupa oleh kelompok tertentu untuk mendapatkan kesan dan citra politik tertentu, atau setidaknya untuk menurunkan kredibilitas pemerintah dan ABRI. Beberapa indikator terasa jelas membenarkan adanya rekayasa terselubung antara lain: (a) Tidak mungkin massa melakukan perusakan serentak dan mengarah ke sasaran spesifik yang berbau etnis dan SARA jika tidak ada yang mengatur dan mengarahkan. (b) Taktik "hit and run" yang dilakukan oleh para perusuh. (c). Hanya mereka yang memahami psikologi massa

${ }^{38}$ Ivan Haryanto (alih bahasa), Batu-batu Tersembunyi dalam Pondasi Kita (Surabaya: Yayasan Kasih dalam Perbuatabn, 2000) 150.

${ }^{39}$ Badan Kerja Sama gereja-gereja se-Jawa 2000.
Barat, Natal Kelabu di Tasikmalaya (Bandung: Badan Kerja Sama Gereja-gereja se-Jawa Barat, 1997) 42. 
yang mampu menggiring massa untuk tetap bergerak dan berekasi.

Mantan Mensesneg Moerdiono ${ }^{40}$ mengatakan bahwa pemerintah menyesal terjadinya kerusuhan Situbondo, Jawa Timur yang mengakibatkan lima orang tewas. Kebebasan beragama merupakan hal asasi manusia yang paling asasi. Kebebasan itu juga bukan pemberian pemerintah ataupun golongan.

Sejak Yudhoyono menjadi Presiden Republik Indonesia pada Desember 2004, ada kenaikan dalam serangan terhadap kaum Ahmadiyah, Kristen, Syiah, dan minoritas agama lain. Menurut data PGI bahwa lebih dari 430 gereja diserang, dipaksa tutup atau disegel, maupun dibakar sejak 2004. Menurut statistik Kementerian Agama pada 2010, Indonesia memiliki lebih dari 243.000 masjid dan sekitar 59.000 gereja. Dengan demikian terjadi ketidakseimbangan pertumbuhan keagamaan di Indonesia adalah 6 (masjid, bukan musola) banding 1 (gereja). Pemerintah perlu berkomitmen kembali untuk menegakkan kebebasan beragama bagi semua komunitas. Namun jika kekuatan (ketidakseimbangan pertumbuhan) diberikan pada kaum ekstremis (mayoritas), Indonesia

\footnotetext{
${ }^{40}$ Surya, 12 Oktober 1996.

41,'Indonesia: hendtikan pembongkaran gereja";

http://www.hrw.org/id/news/2013/03/28/indonesiahentikan-pembongkaran-gereja (Diakses 23 Maret 2014).
}

hanya akan menjadi kian terpecah-belah secara sosial dan mengusung kekerasan di masa depan. ${ }^{41}$

Lebih dalam lagi adalah "Pemaksaan" agama juga terjadi di Aceh di mana wanita nonmuslim di Indonesia diminta memakai jilbab atau pakai muslimah bila hendak masuk di Aceh untuk menghormati muslim di Aceh. ${ }^{42}$ Selanjutnya dicatat bahwa Tim Gegana (Polda) Aceh melakukan identifikasi ledakan granat di depan Kantor PA Kec.Lueng Bata di Banda Aceh, Selasa (11 Maret 2013).Selanjutnya Zonadamai.com-Yayasan Lembaga Bantuan Hukum Indonesia (YLBHI) merilis sejak April 2013 hingga 18 Maret 2014 terjadi 32 kejahatan terkait pemilu di Nanggroe Aceh Darussalam. Daftar tersebut meningkat dibanding kondisi jelang pemilu tahun 2009 yang hanya 20 peristiwa. Sedangkan jelang pemilihan Gubernur dan Wakil Gubernur Aceh pada tahun 2012 jumlahnya mencapai 22 peristiwa. Dengan rincian adalah 32 kejahatan yang terjadi terdiri dari tujuh kasus penganiayaan, enam pembakaran mobil, empat pengancaman, tiga pembunuhan, tiga penculikan, tiga pembakaran posko, dua penembakan posko, dua pelemparan granat kantor, satu perusakan mobil, dan satu aksi

\footnotetext{
${ }^{42}$ https://www.facebook.com/felix.kwetiau/p hotos/a.470427573063730.1073741828.4700407964 35741/479137368859417/?type=1\&theater (Diakses 23 Maret 2014).
} 
pengeroyokan. Di samping itu, juga terdapat 18 pelanggaran pidana jelang Pemilu 2014 yang terdiri dari 15 perusakan alat peraga, dua kampanye di luar jadwal, dan satu pemalsuan dokumen. Maka, jika angka tersebut ditotal dengan jumlah kejahatan menjelang pemilu menjadi 50. Data yang diperoleh YLBHI bersama LBH Banda Aceh menunjukkan sejak April 2013 hingga 17 Maret 2014 setidaknya ada 50 peristiwa. ${ }^{43}$

\section{IMPLIKASI}

"Inilah Aku, Utuslah Aku” (Mrk. 16: 14-18) Suatu Amanat Penderitaan yang merupakan salah satu dari lima sumber "amanat agung" ini (bdk. Mat. 28:18-20; Luk. 24:46-49; Yoh. 20:11-23; Kis. 1:8) memberikan gambaran apa yang mesti orang Kristen lakukan dalam hidupnya sehari-hari. Di sini orang Kristen disadarkan kembali akan tugasnya sebagai orang Kristen.

Dalam Markus 16: 15 mengatakan, "Pergilah ke seluruh dunia, beritakanlah [khrneaten; "preach": khotbah; mengajar; menyebarkan kata-kata nasehat] Injil kepada segala mahkluk. Kata "khrneaten"; "preach" aktif intensif, artinya terus-menerus dilakukan tanpa berhenti dan melalui proses yang panjang. Jadi, bukan sekali saja memberitakan Injil dan berhenti, tetapi

\section{АCEH";}

43“"LBH : 32 KEJAHATAN PEMILU TERJADI DI http://zonadamai.com/2014/03/19/lbh-32-kejahatanpemilu-terjadi-di-aceh/ (Diakses 24 Maret 2014). menjadi proses: didoakan, bisa berkhotbah; bisa mengajar; atau menyebarkan Injil, lalu kembali didoakan. Hal itu terus-menerus dilakukan hingga orang itu benar-benar mengerti apa maksud isi pemberitaan Injil.

Jadi, bagaimana caranya agar Injil bisa disebarkan dengan cepat ke segala pelosok? Umumnya, orang pengerti bahwa pendeta atau penginjil melakukan pemuridan terhadap majelis gereja (tua-tua gereja), dan biarlah majelis itu melakukan pemuridan terhadap jemaat yang lain. Pemikiran ini tidaklah salah tetapi yang cukup ideal bila orang Kristen adalah bisa menggerakan "kaum awam". Kenapa orang awam? Karena, seseorang yang belum percaya bila didekati orang awam maka tidak takut dan terbuka. Tetapi bila didekati seorang pendeta atau penginjil, ia sudah menutup diri. Orang awam adalah media yang efektif untuk melakukan penginjilan. Jadi, perlu dikembangkan orang-orang Kristen menjadi jemaat yang misioner.

Markus 16: 16 "Siapa [seseorang] yang percaya dan dibaptiskan akan diselamatkan, tetapi siapa yang tidak percaya akan dihukum". Ayat 16 adalah salah satu konsekuensi pemberitaan Injil. Percaya berarti seseorang beriman: percaya Yesus Kristus sebagai Juruselamatnya. 
"Dibaptiskan": berarti seseorang itu dijadikan sah menjadi anggota orang-orang percaya (gereja). Jadi, orang percaya itu hidup dalam lingkungan yang baru adalah bersama-sama bersekutu dalam rumah Tuhan. Tapi, bila ia tidak percaya, maka ia binasa. Calvin mengatakan bahwa ayat ini adalah penentuan kehidupan kekal bagi seseorang. Ini suatu kebutuhan manusia. Anugerah dari Allah dan manusia hanya meresponi dengan jalan ketaatan terhadap ketentuan yang telah diberikan-Nya. ${ }^{44}$ Di sini bahwa Allah ikut campur tangan. Bekerja bukan sendirian, melainkan Bersama Allah.

Markus 16: 17 "Tanda-tanda [shmeia; signs; tanda-tanda] ini akan menyertai orang-orang yang percaya: mereka akan mengusir setan-setan demi namaKu, mereka akan berbicara dalam bahasa-bahasa yang baru bagi mereka”. Lalu, ayat 18 "mereka akan memegang ular, dan sekalipun mereka minum racun maut, mereka tidak akan mendapat celaka; mereka akan meletakkan tangannya atas orang sakit, dan orang itu akan sembuh.”

${ }^{44}$ Calvin's New Commentaries, A Harmony of the Gospel Matthew, Mark and Luke (Trans. A.W. Morrison; Grand Rapids: WM. B. Eerdmans Publishing Company, 1972) 3: 253.

${ }^{45}$ Tanda-tanda Alkitab: Tongkat Musa, 10 tulah, tiang api-tiang awan, Yunus-ikan besar, bintang bagi orang Majus (tempat kelahiran Yesus), tempat Paskah: laki-laki mengangkat tembayan di kepala (Mark 14:12-14), Paulus menyebut dirinya "Budak
Kata shmeia (sama dengan 'ot bhs. Ibrani) mempunyai beberapa arti: Pertama, sesuatu untuk menyampaikan pesan istimewa. Tanda-tanda ini digunakan Allah kepada nabi-nya (dalam PL) atau rasulnya (PB). Kedua, karya Allah, atau bukti kehadiran Allah yang aktif di tengah-tengah umat-Nya. Ketiga, karya Iblis contohnya Wahyu 13:16: tanda binatang (kharagma) tanda anti Kristus. ${ }^{45}$

"Kuasa Allah" bersama-sama orangorang percayanya membuat mujizat. 1stilah "kuasa”, bukan hanya sekedar sesuatu yang meyakinkan orang dalam hatinya, tetapi kuasa Yesus mengalahkan penyakit dan setan. Pada dasarnya kuasa Allah sebagai “dasar pelaksanaan" amanat ini (bdk. Mat 28: 19-20: "Tuhan senatiasa menyertai kita selamanya"). Kuasa menjadi perlengkapan rohani orang-orang percaya (bdk. Yoh 20:1123).

Jadi, ada empat hal yang perlu dicatat sebagai berikut: Pertama, tugas spiritual adalah mengarahkan seseorang untuk mempunyai komitmen melalui Roh Kudus. Ia percaya Yesus sebagai Juruselamatnya. Kedua, tugas biblika adalah menjelaskan

Kristus" (2 Kor 11:23-27), budak Galatia merajang tubuh (tanda bakar) Yesus (Gal 6:17). Tapi, pada "semeia" (ayat di atas) cenderung mempunyai arti "karya Allah, atau bukti kehadiran Allah yang aktif di tengah-tengah umat-Nya". Apalagi diperkuat dengan kata "demi nama-Ku", jelas mengarah pada "membuktikan kekuasaan Allah ada hadir dan berjaya di dunia ini” (bdk. Yoh 2:11; 4:54; 12:18). 
doktrin keselamatan dan doktrin-doktrin lainnya kepada seseorang. Ketiga, tugas iman adalah mengarahkan agar seseorang mempunyai pertumbuhan iman yang baik: hidup tidak saja sebagai orang Kristen tetapi taat kepada Allah dan menjalan jalan kehendak Allah. Keempat, tugas kemanusiaan adalah ia sebagai alat untuk membantu menyelesaikan persoalanpersoalan yang sedang dihadapi seseorang.

\section{Implikasi Orang Kristen terhadap Konteks}

Dalam gereja yang tidak terlihat, orang Percaya menempatkan dirinya sebagai "body of Christ", dan Yesus adalah kepalaNya. Di sini, banyak orang Percaya yang belum mengerti konsep "body of Christ", dan itu terbukti orang Percaya dalam gereja yang terlihat selalu menggunakan hukumhukumnya sendiri, daripada melakukan hukum Allah. Orang Percaya ini merasa apa yang dikatakan adalah kebenaran dan mereka bangga terhadap kebenaran yang telah diputuskan, dipegang, dan dijalankan kepada jemaat gerejanya.

"Tubuh Kristus" merupakan arena persekutuan orang-orang percaya. Tubuh Kristus adalah jemaat Allah yang hidup menyebar di seluruh dunia dengan struktur Kristus sebagai "kepala tubuh", yaitu jemaat (Kol. 1:18a). Hal ini disebabkan karena:
"Kristus memperdamaikan segala sesuatu dengan Diri-Nya, baik yang ada di bumi, maupun yang ada di sorga, sesudah Ia mengadakan pendamaian oleh darah salib Kristus. Juga kamu yang dahulu hidup jauh dari Allah dan yang memusuhi-Nya dalam hati dan pikiran seperti yang nyata dari perbuatanmu yang jahat, sekarang diperdamaikan-Nya, di dalam tubuh jasmani Kristus oleh kematian-Nya, untuk menempatkan kamu kudus dan tak bercela dan tak bercacat di hadapan-Nya" (Kol. 1: 20-22).

Sebagai tubuh "Kristus" orang-orang Kristen memang mempunyai nilai penderitaan yang berbeda dibandingkan dengan orang yang belum percaya. Paul mengatakan bahwa ketika penderitaan itu datang kepada kita [orang percaya], maka kita bertanggung jawab kepada penderitaan itu. Di sini penderitaan orang percaya [new creation] berbeda dengan penderitaan sebelum percaya [old creation]. Sebelum percaya, ia menderita sebagai orang belum percaya dan ia percaya, ia menderita sebagai orang percaya. ${ }^{46}$

Penderitaan (patemasi, sufferings) suatu pencobaan (purosei, trials) bagi kehidupan orang Kristen, karena itu purosei pada ayat 12 dikatakan "janganlah kamu heran akan nyala api siksaan yang datang kepadamu" (1 Ptr. 4: 12-19).

Penderitaan ini merupakan karakter orang-orang Kristen. Jadi, sudah menjadi hal yang wajar saja. Justru karena menderita maka orang Kristen menjadi bahagia dan

\footnotetext{
${ }^{46}$ Paul J. Lindell, The Mystery of Pain 12.
} 
tidak membawa kesusahan melainkan kesukaan. Penderitaan ini suatu kehormatan bagi setiap orang untuk menggenapkan penderitaan Yesus Kristus. ${ }^{47}$ Di sini orang Kristen harus meneladani penderitaan Kristus. Peneladanan ini bersifat hidup dan setia dalam penderitaan Kristus. Hal ini harus dilakukan dengan rasa sukacita dan tidak tertekan. Orang Kristen menyerahkan diri sepenuhnya dalam penjagaan Roh Kudus dan hidup berbuat baik, jangan sibuk membicarakan orang lain, membunuh, mencuri, atau melakukan tindak kejahatan. Karena pada waktunya penghakiman tiba,

\footnotetext{
${ }^{47}$ Eksegese 1Pet 4: 12-19 sebagai berikut: Ayat 13: "tois tou Kristou patemasin", diterjemahkan sebagai in the of Christ sufferings. Kalimat tersebut adalah anak kalimat yang memerintahkan pada kata benda patemasin (sufferings; penderitaan). Kata Kriston yang diterjemahkan Christ; Kristus sebagai genetif yang diterjemahkan sebagai of (dari atau milik). Berarti kata benda itu milik genetif, yang artinya penderitaan itu milik Kristus.

Kata patemasin jika diparsingkan adalah dative, plural dengan kata dasar patema. Karena kata patemasin merupakan pokok persoalan yang menunjukkan cara penggunaannya maka bentuk katanya adalah kata benda.

Ayat 15: "me gar tis humon pasketo", diterjemahkan sebagai but let anyone of you suffer. Kalimat tersebut adalah induk kalimat yang menekankan pada kata kerja pasketo (suffer, menderita).

Partikel gar merupakan kata yang menunjuk kalimat sebelumnya (ayat 15), yang berfungsi sebagai pengontras. Dan lebih jelas lagi fungsi kontras ini, diperkuat dengan kata $m i$ (don't, janganlah).

Gar secara umum salah satunya dapat berfungsi sebagai koordinat kata penghubung yang menghubungkan perbatan yang berdiri sendiri atau sebagai bagian dari koordinat kata penghubung yang memulai bergantung dari anak kalimat. Sebagai sebutan dalam membuka kata-kata dari bagian ini, gar adalah seirng digunakan memperlihatkan bahwa satu batas kebebasan dukungan simatik yang lain. ${ }^{47}$ Tapi arti khusus pada dapat diterjemahkan "sungguhsungguh" (indeed), "pasti" (certainly), "tentu saja"
}

dan semua orang termasuk orang Kristen tidak luput dari penghakiman tersebut.

Jadi, memang ciri orang Kristen adalah hidup menderita dalam Kristus. Penderitaan orang Kristen merupakan amanat Allah yang harus dilakukan oleh orang Kristen. Jadi, bukanlah suatu aneh bila tubuh Kristus hidup dalam penderitaan yang disebabkan oleh dunia.

\section{Implikasi Gereja terhadap Konteks}

Jalan mengatasi penderitaan 1 Petrus

4: 12-19 ini adalah: Pertama, bersekutu (koinoneit; share) dengan Kristus supaya

(surely), "betul-betul" (actually), dan lainnya. Pada ayat 15 , menunjuk pada arti "pasti" (certainly). ${ }^{47}$ Dan ini merupakan karakter dasar dari ayat tersebut, yang intinya mengatakan, "tidak boleh satu orang pun yang menderita".

Kata kerja pasketo bila diparsing menjadi: orang ke-3, present imperatif dengan kata dasar pasko.Imperatif adalah digunakan untuk mengekspresikan berbagai jenis perintah. Maka, bila dikelompokkan pasketo termasuk jenis perintah imperative of prohibition (bentuk perintah dari larangan). Ini terbukti adanya kata $m i$, yang menunjuk pada berhenti untuk beraktifitas. ${ }^{47}$ Jadi, dikatakan present imperative berarti berhenti saat ini (sekarang) untuk melakukan aktifitas pasketo sebagai pembunuh, pencuri, penjahat, atau pengacau.

Ayat 19: "hoste kai oi paskontes", diterjemahkan sebagai wherefore also they who suffer. Kalimat ini termasuk anak kalimat. Partikel hoste kai menunjuk induk kalimat sebelumnya.

Kata kerja paskontes bila diparsingkan adalah: nominatif, plural, maskulin, participle present, dengan kata dasar pasko.Participle adalah a verbal adjective; mempunyai karakter dari kata kerja dan mempunyai karakter dari kata sifat. Kata paskontes termasuk the causal participle (kata partisif sebab). Hal ini dibuktikan dengan kata hoste kai, yang diterjemahkan "karena itu" atau "sebab itu" (LAI).

Dengan konteks ini, ayat 19 merupakan kesimpulan dari ayat 12-18. Kata "sebab itu", menyimpulkan mereka (orang Kristen yang berlatar belakang kafir) secara present (sekarang) lebih baik menderita karena kehendak Allah. 
kamu bersukacita (chairete; rejoice) pada waktu Allah menyatakan kemuliaan-Nya (ay. 13). Kedua, berbuat baik (agatoroia; welldoing) dengan iman Kristus kepada sesama manusia (ay. 19). ${ }^{48}$

Cara mengatasi penderitaan ini juga ditawarkan oleh Augustinus agar manusia itu memperoleh [dalam jalan] hidup damai yang kekal. Meskipun Augustinus melihat sangat duniawi dalam cara berpikir manusia mengenai peperangan tetapi ada nilai-nilai positif yang bisa manusia ambil, adalah manusia masih mempunyai keinginan untuk hidup damai di dunia. Damai berarti tidak bermusuhan (berselisih, berperang); keadaan tak bermusuhan, tak ada kerusuhan; berbaik kembali, tentram aman. ${ }^{49}$ Berkaitan hal tersebut, maka David R. Plaster setuju dengan pendapat Augustinus bahwa inti dari

\footnotetext{
${ }^{48}$ Surat 1 Petrus 4: 12-19 merupakan model yang sangat ideal dalam melihat kondisi penderitaan orang Kristen dan gereja pada masa kini. Perikop ini mengajak pembaca surat 1 Petrus - masyarakat Yunani kelas dua - dalam penghiburan karena penganiayaan.

Penderitaan dari kata "derita" (pascho, yang dalam PB dipakai sebanyak 42 kali). Penderitaan (patemasi; sufferings) dalam perikop ini merupakan suatu pencobaan (purosei; trials) bagi kehidupan orang Kristen, karena itu purosei pada ay. 12 dikatakan: "Janganlah kamu heran akan nyala api siksaan yang datang kepadamu."

Jalan mengatasi penderitaan 1 Petrus 4: 1219 ini adalah: Pertama, bersekutu (koinoneit; share) dengan Kristus supaya kamu bersukacita (chairete; rejoice) pada waktu Allah menyatakan kemuliaanNya (ay. 13). Kedua, berbuat baik (agatoroia; welldoing) dengan iman Kristus kepada sesama manusia (ay. 19).

Bila orang Kristen menderita karena kekristenannya, maka ia harus berbahagia karena Roh Allah menjaga ia agar ia tidak jatuh dalam penderitaan
}

adanya bermusuhan karena adanya orang yang suka damai, dan rasa suka damai dijadikan senjata untuk bermusuhan. ${ }^{50}$ Karena itu, orang Percaya perlu melakukan tiga hal bila negara mengajaknya berperang: pertama, orang Percaya harus percaya kepada kehendak Allah. Karena Allah sudah menyetujui adanya negara, maka apa yang diperintahkan negara perlu kita gumuli. Kedua, asalkan apa yang dilakukan oleh negara kita tidak melanggar ajaran Alkitab. Ketiga, melayani manusia dan negara untuk bersekutu dengan Allah. Artinya, manusia perlu hidup rukun di bumi ini.

Tertulianus dan Origenes mengatakan bahwa menjadi tentara tidak sesuai dengan iman Percaya. ${ }^{51}$ Jadi, pada prinsipnya bila keinginan untuk memuaskan diri manusia itu dipenuhi maka benar apa

(ay. 14), tapi kalau ia menderita karena melanggar norma-norma Allah (berperang, membunuh, mencuri, merampok, atau mengacau), maka ia akan binasa (ay. $15)$.

Penderitaan dalam 1 Petrus 4: 12-19 ini merupakan ciri orang-orang Kristen. Karena kebenaran orang Kristen menjadi bahagia. Karena menderita orang Kristen tidak membawa kesusahan, melainkan kesukaan. Penderitaan ini suatu kehormatan bagi setiap orang untuk ikut dalam teladan penderitaan yang sudah selesai dilakukan oleh Yesus Kristus (Yoh 19:30). Jadi, menjadi orang Kristen berarti menjadi pengikut Kristus dalam segala hal yang Yesus lakukan.

${ }^{49}$ Marcus Dods. The City of God (Chicago: Encyclopaedia Britannica, 1973) XIX. 12, 687.

${ }^{50}$ David R. Plaster "The Christian and War: A Matter of Personal Conscience," Grace Theological Journal, Vol. 6. No.2 (Fall 1985) 449.

${ }^{51} \mathrm{~J}$. Hastings (ed.), Dictionary of the Apostolic Church (Grand rapids: Baker Book House,1978) 2:656. 
yang dikatakan Augustinus adalah akan terjadi malapetaka - manusia tidak bisa hidup tanpa peperangan. Tetapi, adanya hasrat untuk damai - meskipun hanya dijadikan alat peperangan - merupakan langkah terwujudnya gambar kerukunan sesama manusia. ${ }^{52}$ Dan ini yang menghibur orangorang Percaya yang menderita karena Kristus di Indonesia dalam menerima tekanantekanan dari pihak luar kekristenan. Hasrat damai ini mengajak sesama manusia di Indonesia hidup rukun. Berkaitan hal ini, maka mantan Menteri Agama Tarmizi Taher, ${ }^{53}$ mengatakan:

Sekarang harus disadari bahwa umat Islam di dunia terbanyak di Indonesia. Jadi umat Islam harus tahu akan tanggung jawab bangsa ini, dan kita harus hidup rukun dengan sesama umat agama. Yang Kristen bukan indekos di Indonesia, dan juga umat Islam bukan indekos di negeri ini, tetapi semuanya pemilik sah di negeri ini. Oleh karena itu hubungan Islam dan Kristen di Indonesia sangat menentukan jalannya bangsa ini di masa depan.

PB menekankan orang Percaya untuk tidak bermusuhan. Orang Percaya mempunyai rasa damai bukan berakar dari duniawi, melainkan dari Allah. Perdamaian orang Percaya mengacu kepada karya Yesus yang menyelesaikan semua soal akibat dosa

\footnotetext{
${ }^{52}$ Mohammad Natsir dalam artikel berjudul "Tanpa Toleransi Takkan Ada Kerukunan" dalam buku yang diedit oleh Lukman Hakiem, Fakta dan Data (Jakarta: Majalah Media Dakwah, 1991) 49 mengatakan bahwa kita mengharap: para zu'ama dan ulama kita, para intellegenzia kita yang ada di kampus-kampus, para pembina umat di lapisan uratmasyarakat - semuanya, sama-sama menyadari dan
}

manusia, dan yang memulihkan hubungan manusia dengan Tuhan Allah (Rm. 5:10). Jadi, apa yang terjadi di Indonesia ada titik terang hasrat kerukunan sesama manusia, tetapi baru ada titik terang -- keinginan semua manusia untuk rukun - bagaimana merealisasinya? Alkitab mengajarkan agar orang-orang Percaya bisa menjadi saksi Allah. Allah mengajarkan untuk hidup sebagai saksi-Nya (Yes. 43:10,12; Luk. 24:48; Yoh. 15:27; Kis. 1:8).

Bagaimana caranya menjadi saksi Allah? Para pemimpin gereja perlu mengarahkan jemaatnya untuk mengekspresikan kasih Allah yang mulai dikalahkan oleh perbuatan duniawi". ${ }^{54} \mathrm{Jadi}$, orang Percaya harus hidup jujur, penuh persaudaraan, bermoral, hidup benar. Semua itu kita bangun dalam hidup kita bersama-sama. Firman Allah dinyatakan kepada kita agar kita hidup dalam kebenaranNya. Anak-anak Allah diberi iman untuk bersaksi kepada orang lain. Orang Percaya mempraktekkan nilai-nilai kasih Allah. Jangan sampai seperti apa yang dikatakan Yesaya 17:9: "Betapa liciknya hati, lebih licik dari pada segala sesuatu, hatinya sudah

menghayati sejarah yang kita umat Islam sedang hadapi sekarang. Agar jangan: kata tak berjawab, gayung tak bersambut. Tanpa toleransi, takkan ada kerukunan."

${ }^{53}$ Suara Pembaharuan, 4 Januari 1997.

${ }^{54}$ William E. Nix, "The Evangelical and War," Journal of the Evangelical Theologic Society 13:3 (Summer 1970) 146. 
membatu: siapakah yang dapat mengetahuinya?"

Kita bersaksi kepada siapa saja Islam, Katolik, Budhha, Hindhu, Kepercayaan, atau kepercayaan apa saja. James $^{55}$ dengan tegas menyarankan bahwa orang Percaya harus memberi masukan kehidupan kasih Allah untuk orang-orang Islam. ${ }^{56}$ Orang Percaya mendemokan kasih Allah bukan untuk mematikan kasih Allah, sehingga orang Islam semakin menjauh dan semakin mempunyai akar kebencian kepada orang Percaya.

Allah tidak hanya meminta anak-anak sebagai saksi-Nya, tetapi Ia sendiri juga sudah mendemokan kasih-Nya kepada manusia. Melalui pilihannya, orang Israel Allah telah memelihara mereka. Allah bertindak menyelamatkan orang Israel. Allah turun campur tangan dalam kehidupan manusia, khususnya memberi teladan untuk orang-orang Israel. Bahkan puncaknya, melalui Yesus Allah bersaksi bagi keselamatan umat manusia. Kesaksian Allah didasarkan kemurahan dan kasih karuniaNya. Kesaksian-Nya dalam PB sama dengan PL: Allah menyelamatkan, mengirim melalui kuasa dan kekuatan-Nya. Dalam PB, Ia membangkitan Yesus Kristus dari kematian-

\footnotetext{
${ }^{55}$ James Paul Dretke, A Christian Approach to Muslims Reflections from West Africa (Pasadena: William Carey Library, 1979) 268 halaman.

${ }^{56}$ Ini mengingatk Islam adalah mayoritas di Indonesia, dan konflik-konflik agama di Indonesia
}

Nya (Kis. $1: 22 ; 2: 32 ; 3: 15 ; 4: 33 ; 5: 32 ; 10: 39$; $41 ; 13: 31)$.

Jadi, orang Percaya bersaksi dalam segala hal: kesengsaraan dari dosa dan konsekuensinya, ketidakberdayaannya, ketidak-ada-harapannnya, keputusasaannya, yang semua itu karena kemurahan Allah, sehingga orang Percaya menjadi manusia yang tegar: hidup dalam kedamaian karena imannya.

Implikasi Pelayanan Misi terhadap Konteks Implikasi pelayanan misi terhadap konteks adalah tugas dialog oleh orang-orang Percaya. Orang Percaya tidak saja bersaksi akan hidupnya yang benar di hadapan Allah, tetapi juga melatih dirinya untuk bisa merubah orang lain hidup rukun dengan sesamamanya, termasuk hidup dengan orang-orang Percaya. Salah satu melakukan perubahan itu dengan berdialog. ${ }^{57}$ Orang Percaya mempunyai tugas untuk berdialog kepada sesama manusia. Misalnya orang percaya bisa berdialog dengan orang Islam. Bila orang Percaya dan orang Islam menghayati bersama nilai-nilai dan kepentingan yang mereka miliki bersama, maka pertumbuhan hidup rukun dapat tergalang dan dapat diharapkan akan

terjadi dengan Islam. Jadi, kita perlu memperhatikan Islam secara khusus dalam kerukunan beragama.

${ }^{57}$ Baca James Paul Dretke, A Christian Approach to Muslims Reflections from West Africa, 270. 
menjelma juga kepada agama lainnya. Kita semua insaf bahwa, meskipun ada perbedaan agama, kita semua termasuk bangsa manusia yang satu dan yang sama, bahwa kita mempunyai luka-luka yang sama, tapi juga cita-cita yang sama, kelemahan yang sama, tapi juga kekuatan yang sama. Jadi, selalu ada ruang untuk memikirkan dan memecahkan bersama soal-soal yang manusia hadapi bersama dan tujuan-tujuan yang manusia kejar bersama.

Di Masjid dapat dikatakan bahwa hubungan orang Percaya-Islam dihayati terutama di tingkat hubungan antara manusia pribadi: di bidang pekerjaan dan profesi, di bidang rekreasi, dalam lingkungan antara keluarga. Di tingkat pergaulan pribadi itu dapat kita menghayati kekayaan pertemuan orang yang karena sejarah, kebudayaan dan agama telah terpisah, tapi yang mulai saling mengenal karena bekerja sama dan bergaul bersama dalam kehidupan sehari-hari. ${ }^{58}$ Dalam konteks di atas, maka mantan Presiden Abdurrahman Wahid saat menutup Sidang Agung Gereja Katolik 2000 di Jakarta, 5/11 lalu mengatakan:

Bangsa Indonesia dalam membangun demokrasi yang didambakannya sekarang ini, hendaknya tidak lagi menggunakan okol atau kekuatan fisik. Sudah saatnya

${ }^{58}$ Baca Mgr. P. van Diepen, Augustinus Tahanan Tuhan (Yogyakarta: Kanisius, 2000) 186 dikatakan Berhubung dengan Sinode pan-Afrika yang atas undangan Paus Yohanes Paulus II diadakan pada tahun 1992, para Uskup Aljazair, dalam Surat Gembala mereka (8 Juni 1990), menyapa umatnya sebagai berikut: "Sejak Konsili Vtikan II, Gereja mengembangkan dialog atau adu argumentasi secara terus-menerus dengan akal sehat. ${ }^{59}$

Dialog ini bertujuan untuk memberi wawasan pengertian keagamaan masingmasing agama: Krsiten-Islam. Tentu saja orang Percaya mendialogkan (mengkomunikasi) Injil. Isi dialog "pesan kematian Kristus di kayu salib". Dialog itu tidak perlu bertele-tele, tetapi singkat dan jelas. Dialog itu bukan compromised, bukan berdebat, atau tawa menawar. Dialog kebenaran dan memberitakan ketaatan iman seseorang dalam suatu bentuk. Dan yang paling penting, hasil dialog adalah "diterima" atau ditolak".

Dialog itu sharing mengenai kasih karunia, yang perlu didengarkan, dipelajari, dan didiskusikan. Dialog itu perlu dimuridkan oleh orang-orang Percaya seperti Yesus memuridkan 12 murid-Nya. Dan murid-murid Yesus memuridkan banyak murid lainnya. Matius 10:5 atau Lukas 10:3 mengatakan "pergilah": ini adalah salah satu bagian dari tugas berdialog itu. Murid-murid berdialog kepada sesama manusia - dialog dengan orang tidak percaya.

mengerti dengan lebih jelas tanggung jawabnya dalam hubungannya dengan umat beriman tradisitradisi religius lain. Pembentukan suatu hubungan yang bersifat kerukunan dan persaudaraan antara umat Kristen dan umat Islam, merupakan tugas utama Gereja masa kini."

${ }^{59}$ Kompas, 6 November 200. 
Dialog tidak hanya cara komunikasi dan sharing mengenai kebenaran, tetapi itu adalah tes bagi orang Kristen terhadap kebenaran yang kita miliki. Dengan berdialog pemahaman kebenaran kita semakin benar dan kokoh. Karena itu, dialog adalah bagian kegiatan orang-orang Percaya yang dilakukan setiap hari dan di mana saja ia berada -- berdialog di pasar, sedang menunggu bis, sedang menunggu seseorang.

Ketika kita menyediakan waktu untuk berdialog antara orang Percaya dan Islam, maka kita hidup dalam pekerjaan Roh Kudus yang terus menerus membentuk kita (Yoh 14:16; 15:26; 16:7-15). Zakharia 4:6 mengatakan bahwa apa yang kita lakukan bukan dengan keperkasaan atau kekuatan kita, melainkan dengan Roh Allah.

Jadi, tugas kita adalah berdialog dan biarlah Allah yang menentukan hasilnya: apakah ia bisa kita memenangkan dan hidup dalam kerukunan orang-orang Percaya, atau tidak, semua itu Allah yang bekerja.

\section{KESIMPULAN}

Penderitaan ialah tekanan yang dihadapi seseorang yang datang dari luar dirinya untuk memberikan pengaruh yang baik kepada orang tersebut. Penderitaan bagi manusia tidak dapat ditolak ketika ia lahir di bumi. Karena manusia itu berdosa maka penderitaan itu manusia bawa sejak lahir. Tetapi penderitaan orang yang bukan percaya dengan orang percaya berbeda. Kalau orang yang bukan percaya adalah penderitaan karena dunia tetapi kalau orang percaya menderita karena Kristus.

Orang percaya yang hidup di bumi Indonesia adalah benar-benar menderita karena Kristus - gereja dibakar, orang percaya yang dianiaya, orang percaya yang difitnah dan ditekan dalam segala kehidupannya, bahkan orang-orang percaya yang terbunuh.

Implikasi penderitaan yang dialami orang-orang percaya di Indonesia adalah memang amanat Agung Kristus. Jadi orang percaya maupun gereja wajib melakukan misi Allah adalah memenangkan jiwa-jiwa yang tersesat dalam penderitaannya dengan cara adalah: menjadi saksi Allah dan dialog untuk memberitakan Injil.

\section{DAFTAR PUSTAKA}

"Indonesia: hendtikan pembongkaran gereja"; http://www.hrw.org/id/news/2013/ 03/28/indonesia-hentikanpembongkaran-gereja (Diakses 23 Maret 2014).

Badan Kerja Sama gereja-gereja se-Jawa Barat, Natal Kelabu di Tasikmalaya. Bandung: Badan Kerja Sama Gereja-gereja se-Jawa Barat, 1997.

Calvin's New Commentaries, A Harmony of the Gospel Matthew, Mark and Luke. Trans. A.W. Morrison. Grand Rapids: WM. B. Eerdmans Publishing Company, 1972. 
Cole, R. Alan. Mark, TNTC. Grand Rapids: Eerdmans, 1989.

Diepen, Mgr. P. van. Augustinus Tahanan Tuhan. Yogyakarta: Kanisius, 2000.

Dods, Marcus. The City of God. Chicago: Encyclopaedia Britannica, 1973.

Douglas, J.D. New Bible Dictionary. England: Inter-Varsity Press, t.th.

Dretke, James Paul. A Christian Approach to Muslims Reflections from West Africa. Pasadena: William Carey Library, 1979.

Editorial Berita FKKI, Edisi 20, Agustus 2000.

Harrison, Everret F. Baker's Dictionary of Theology. Michigan: Baker Book House, 1988.

Haryanto, Ivan (alih bahasa). Batu-batu Tersembunyi dalam Pondasi Kita. Surabaya: Yayasan Kasih dalam Perbuatabn, 2000.

Hastings, J. (ed.). Dictionary of the Apostolic Church. Grand rapids: Baker Book House, 1978.

http://intanshawolarea.wordpress.com/2013/ 10/07/kasus-kasus-pelanggaranham-di-indonesia/ (Diakses 20 Maret 2014).

http://zonadamai.com/2014/03/19/lbh-32kejahatan-pemilu-terjadi-di-aceh/ (Diakses 24 Maret 2014).

https://www.facebook.com/felix.kwetiau/ph otos/a.470427573063730.1073741 $828.470040796435741 / 47913736$ $8859417 /$ ?type $=1 \&$ theater (Diakses 23 Maret 2014).

Jeremias, Joachim. New Testament Theology I: Proclamation of Jesus. London: SCM Press, 1971.

Kompas, 6 November 200.

Lewis, C.S. The Problem of Pain. New York: The Macmillan Co., 1994.

Lindell, Paul J. The Mystery of Pain. Jerman: Editions Trobisch, 1982.

Lumintang, Stevri I. Misiologia Kontemporer. Batu: Departemen Multi-Media YPPII, 2009.
Natsir, Mohammad. "Tanpa Toleransi Takkan Ada Kerukunan" dalam buku yang diedit oleh Lukman Hakiem, Fakta dan Data. Jakarta: Majalah Media Dakwah, 1991.

Nix, William E. "The Evangelical and War," Journal of the Evangelical Theologic Society 13:3 (Summer 1970) 146.

Plaster, David R. "The Christian and War: A Matter of Personal Conscience," Grace Theological Journal, Vol. 6. No.2 (Fall 1985) 449.

Sockman, Ralph W. Makna Penderitaan. Malang: Gandum Mas, tp. th.

Song, C. S. "Jesus Christ - The Life of the World - an Asian Meditation" East Asia Jurnal of Theology, Vol.1 No. 1 (1983).

Song, C. S. Third-Eye Theology. Maryknoll: Orbis Books, 1979.

Song, C.S. "Dunia Citra-citra dan Lambanglambang", Persetia of Theological Education Series, 1992.

Song, C.S. Jesus and the Reign of God. Minneapolis: Augsburg Fortress, 1993.

Song, Choan-Seng. Allah yang Turut Menderita. Jakarta: Gunung Mulia, 1993.

Song, Choan-Seng. Christian Mission in Reconstruction: An Asian Analysis. Maryknoll: Orbis Books, 1977.

Suara Pembaharuan, 4 Januari 1997.

Surya, 12 Oktober 1996.

Tahalelel, Paul, dkk. (ed.). Beginikah Kemerdekaan Kita. Surabaya: Forum Komunikasi Kristiani Surabaya, 1997.

Thomas, M.M. Man and the Universe.

Thomas, M.M. The Christian Rerponse in the Asian Revolution. London: 1966.

Yewangoe, A.A. Theologia Crucis di Asia. Jakarta: Gunung Mulia, 1989. 